\title{
Assessment of the degree of technogenic load in the zone of influence of CHP-5 on snow cover
}

\author{
(C) Svetlana G. Skugoreva, ${ }^{1,2} *^{+}$Anna I. Fokina, ${ }^{1}$ \\ Olim M. Abdukhalilov, ${ }^{1}$ and Tamara Ya. Ashikhmina ${ }^{1,2}$ \\ ${ }^{1}$ Department of Fundamental Chemistry and Methods of Teaching Chemistry. Institute of Chemistry \\ and Ecology. Vyatka State University. Moskovskaya St., 36. Kirov, 610000. Kirov Region. Russia. \\ Phone: (8332) 35-64-65. E-mail: annushka-fokina@mail.ru. \\ ${ }^{2}$ Biomonitoring Laboratory. Institute of Biology of the Komi Scientific Center, Ural Branch of the Russian \\ Academy of Sciences. Kommunisticheskaya St., 28. Syktyvkar, 167982. Komi Republic. Russia. \\ Phone: (8332) 37-02-77.E-mail: skugoreva@mail.ru
}

\begin{abstract}
*Supervising author; ${ }^{+}$Corresponding author Keywords: snow cover, ionic composition, heavy metals, polycyclic aromatic hydrocarbons, carcinogenic activity, total pollution indicator.
\end{abstract}

\begin{abstract}
Combined heat and power plant (CHP) are sources of environmental pollution and therefore requires continuous control of the flow of pollutants which are generated during their work. One of the leading CHP in the city of Kirov (Kirov region, Russia) is a CHP-5 located in the South-Western outskirts of the city. The aim of the study was to assess the degree of anthropogenic load and the territorial focus of the impact of CHP-5 on the natural environment according to the results of chemical analysis of snow. As indicators of contamination used in the mass concentration of ions of sodium, ammonium, potassium, magnesium, calcium, strontium, zinc, cadmium, lead, copper, fluoride-, chloride-, nitrate-, phosphate- and sulfate-ions; the concentration of polycyclic aromatic hydrocarbons (PAH) in solid phase of snow water, acidity and electrical conductivity.

It was found that the samples of snow water in areas near CHP-5 had a content of inorganic ions and PAHs exceeding the background values. The higher content of ions and heavy metals (HM) differed from forest sites in comparison with meadow.

The highest concentrations of sodium, ammonium, potassium, calcium, magnesium ions, more alkaline reaction of the medium are determined in the snow water of the leeward areas of CHP-5. In comparison with background sites, the highest content of HM ions in snow water was found in samples from sites in the SouthWest direction from the CHP near the place of storage and transportation of coal. The most polluted PAHs are the areas located on the leeward side of the CHP and near the Sovietsky tract. The carcinogenic activity of PAHs in the solid phase of snow water is quite high and varies from 6.79 to $9.71 \mu \mathrm{g} / \mathrm{dm}^{3}$. Maximum electrical conductivity, high concentrations of potassium, calcium, copper, lead, zinc, chloride, nitrate, sulfate ions, increased content of pyrene relative to background, benz $[b]$ fluoranthene, benzo $[a]$ pyrene and benzo $[g, h, i]$ perylene is set for the forest area (4-S-W), located in the south-western direction from the CHP, in the immediate vicinity of storage and transportation of coal. This site is the most polluted of all investigated, the degree of its pollution can be characterized as an average.
\end{abstract}

\section{References}

[1] Coal Combustion Byproducts and Environmental Issues. Eds. K.S. Sajwan, I. Twardowska, T. Punshon, A.K. Alva. Springer. 2006. 231p.

[2] Environmental Contaminants: Measurement, Modelling and Control. Eds. T. Gupta, A.K. Agarwal, R.A. Agarwal, N.K. Labhasetwar. Springer. 2018. 431 p.

[3] Snow survey of the territory of the city of Kirovo-Chepetsk and its environs / Research Report. Ekaterinburg: Institute of Industrial Ecology, Ural Branch of the Russian Academy of Sciences. 1998. 35p. (russian)

[4] V.N. Vasilenko, I.M. Nazarov, I.O. Fridman. Monitoring of snow cover pollution. Leningrad: Gidrometeoizdat. 1985. 181p. (russian)

[5] The official site of the T Plus company: https://www.tplusgroup.ru

[6] A.I. Fokina, E.V. Dabakh, L.I. Domracheva, S.G. Skugoreva, E.I. Lyalina, T.Ya. Ashikhmina, Yu.N. Zykova, K.A. Leonova. Methodical approaches to the chemical and biological diagnostics of the soil of

Kazan. The Republic of Tatarstan. Russia. (C) Butlerov Communications. 2019. Vol.59. No.8. 

technogenically transformed territories. Soil science. 2018. No.5. P.589-600. doi.org/10.7868/S0032180X18050088

[7] FR.1.31.2005.01724 Methods for measuring the mass concentration of fluoride, chloride, nitrate, phosphate and sulfate ions in drinking, mineral, table, medical table, natural and waste water by ion chromatography. Moscow: Aquilon. 2008. 26p. (russian)

[8] FR.1.31.2005.01738 Methods for measuring the mass concentration of ammonium, potassium, sodium, magnesium, calcium, and strontium cations in drinking, mineral, table, medical-table, natural and waste water samples by ion chromatography. Moscow: Aquilon. 2008. 30p. (russian)

[9] MU 08-47/269 Mass concentration of copper, lead, cadmium, zinc, bismuth, manganese, cobalt and nickel in drinking, mineral, natural, sea and treated wastewater. Moscow: LLC Econix-Expert. 2013. 49p. (russian)

[10] RD 52.24.495-2017 Hydrogen indicator of water. Measurement technique potentiometric method. Moscow: Roshydromet. 2017. 12p. (russian)

[11] M 02-14-2007 Atmospheric air and work area air. Methods for measuring the mass concentration of benz[a]pyrene by high performance liquid chromatography with fluoremimetric detection using a Lumakhrom liquid chromatograph. St. Petersburg: Lumex. 2016. 25p. (russian)

[12] Guidelines for assessing the degree of air pollution of populated areas by metals according to their content in snow cover and soil. Moscow: IMGRE. 1990. 15p. (russian)

[13] I.C. Nisbet, P.K. La Goy Toxic equivalency factors views of Environmental Contamination and Toxicology. (TEFs) for polucuclic aromatic hydrocarbons (PAHs). Regulatory Toxicology and Pharmacology. 1992. Vol.16. No.3. P.290-300.

[14] Weather and climate. Weather archive. Kirov region. Kirov: http://www.pogodaiklimat.ru/weather.php?id=27199

[15] S.G. Skugoreva, T.A. Adamovich, G.Ya. Kantor, V.P. Savinykh, T.Ya. Ashikhmina, A.V. Izmestieva Assessment of the degree of contamination of snow cover in the zone of influence of the KirovChepetsk Chemical Works. Theoretical and Applied Ecology. 2011. No.1. P.31-36. DOI:10.25750/1995-4301-2011-1-031-036

[16] N.I. Yanchenko, L.I. Belykh. Comparative assessment of polycyclic aromatic hydrocarbons of snow cover in the emission zone of aluminum production. Optics of the atmosphere and the ocean. 2017. Vol.30. No.1. P.66-71. DOI:10.15372/L0020170109

[17] S.G. Skugoreva, A.I. Fokina, E.I. Lyalina, D.V. Budina, Yu.N. Zykova. Assessment of the state of snow cover in the zone of influence of CHP-5, the city of Kirov. Modern research and development. 2017. No.4(12). P.481-486. (russian) 